Prace Literackie LIX

Wrocław 2019

https://doi.org/10.19195/0079-4767.59.4

ŁUKASZ PIASKOWSKI

ORCID: 0000-0002-3528-4301

Uniwersytet Wrocławski

\title{
Muzyczne nośniki pamięci kulturowej w poezji Jana Lechonia
}

\section{Słowem wstępu}

Powinowactwa muzyczno-literackie poezji Jana Lechonia zauważane są przez badaczy od wielu lat ${ }^{1}$. Nie są tak złożone jak w wypadku poezji innych skamandrytów, na przykład Jarosława Iwaszkiewicza czy Juliana Tuwima² ${ }^{2}$ Jeśli jednak uprościć historię poezji dwudziestolecia międzywojennego, można dokonać podziału na tę, która muzykę traktuje jako kategorię estetyczną współtworzącą poetykę eufonii poszczególnych faktów literackich, oraz tę, która muzykę traktuje jako motyw lub temat. Każdy w ten sposób uproszczony obraz jest niedoskonały, ale ma jedną zasadniczą zaletę — dzięki symplifikacji pewne elementy obrazu widać wyraźniej.

W niniejszym szkicu chciałbym pokazać, w jaki sposób Jan Lechoń tematyzuje muzykę i jakie konsekwencje przynoszą te operacje. Elementy stematyzowane zawsze tworzą pewien złożony zbiór znaczeń. W wypadku poezji Lechonia zauważalna jest tendencja do łączenia pewnych motywów w większe całości. Oznacza to, że operacje poznawcze, których przedmiotem jest doświadczenie mu-

${ }^{1}$ Prace z ostatnich lat, jakie warto wyróżnić: I. Chyła-Szypułowa, Muzyka w poezji Jana Lechonia, „Studia Artystyczne Akademii Świętokrzyskiej” 7, 2007; J. Wiśniewski, Ku harmonii? Poetyckie style stuchania muzyki w wierszach polskich autorów po 1945 roku, Łódź 2013; A. Kotliński, Polonez artyleryjski Jana Lechonia, [w:] Reinterpretacje, red. M. Tramer, A. Wójtowicz, Katowice 2015; G. Ostasz, Bekwark. Jana Lechonia osobowy znak sztuki idealnej, [w:] idem, Śladami poezji czystej, Rzeszów 2017; E. Radion, Audiosfera „Karmazynowego poematu” Jana Lechonia, [w:] Literatura wspótczesna w edukacji polonistycznej, t. 2. Interpretacje - wartości - konteksty, red. U. Kopeć, Rzeszów 2017; eadem, Percepcja wrażeń akustycznych w wierszu Mochnacki Jana Lechonia, „Acta Universitatis Lodziensis. Folia Litteraria Polonica” 2019, nr 1.

${ }^{2}$ K. Kutereba, Muzyczność w poezji dwudziestolecia międzywojennego, [w:] Cóż wiesz o pięknem? Szkice o literaturze, języku, muzyce i filmie, red. T. Mizerkiewicz, W. Ratajczak, Poznań 2007, s. $142-144$. 
zyczne, nie są samodzielnie eksponowane. Dlatego też celem komplementarnym szkicu będzie pokazanie, jak stematyzowane motywy muzyczne wykorzystywane są przez poetę do budowania konstrukcji wyższego rzędu, których naczelnym budulcem jest motyw pamięci.

\section{Pamięć w poezji Lechonia}

Literaturoznawcze badania nad pamięcią, zwłaszcza niemieckojęzyczne, rozwijały się w ostatnich latach bardzo dynamicznie. Także i w Polsce pojawiła się podobna moda badawcza. Cały tak zwany memory boom przyniósł już wiele ciekawych opracowań i bogatą literaturę ${ }^{3}$. W niniejszym szkicu wykorzystane zostaną badawcze ustalenia najbardziej kompatybilne z przyjętym punktem widzenia. Nie będzie to szkic poddający analizie rozbudowane już koncepcje pamięci. Ich bujny rozwój zawdzięczamy takim uczonym, jak chociażby Jan Assmann, Aleida Assmann, Maurice Halbwachs, Pierre Nora, Astrid Erll, Herald Welzer, Günter Butzer i wielu innych, w Polsce zaś Magdalena Saryusz-Wolska, Justyna Tabaszewska, Krzysztof Trybuś czy Elżbieta Rybicka. Szkic, powtarzam, nie będzie miał charakteru teoretycznego studium o pamięci kulturowej, zbiorowej, kolektywnej czy społecznej. Będzie to praca poświęcona wybranym utworom poetyckim Jana Lechonia, które w kontekście pamięciologii można traktować jako medium (lub dokument ${ }^{4}$ ) wytwarzania elementów kultury literackiej, wpływającej pośrednio na kulturę zbiorowości. Poeta to jednostka istniejąca w pewnych ramach społecznych. Jak twierdzi A. Assmann: „Człowiek nie definiuje się bowiem sam przez się, lecz za pomocą więzi i przynależności do innych. [...] Pamięć indywidualną, czyli to, co z zasady odróżnia nas od innych [...], poszerza wspólna pamięć o rzeczach, których wcale nie musimy doznawać osobiście"5. W kontekście literackim swoistym repozytorium pamięci jest tradycja literacka — rozumiana jednak jako ogół doświadczeń kulturowych, a nie jedynie poetologicznych.

Lechoń, mówiąc słowami Aby’ego Warburga, dokonuje aktualizacji tradycji literackiej, która jest pojęciem pokrewnym pamięci ${ }^{6}$. Literatura jako medium ${ }^{7}$

${ }^{3}$ Spośród najważniejszych dokonań badawczych warto wyróżnić te książki, które ukazały się w serii „Nowa Humanistyka”: Od pamięci biodziedzicznej do postpamięci, red. T. Szostek, R. Sendyka, R. Nycz, Warszawa 2013; Pamięć i afekty, red. Z. Budrewicz, R. Sendyka, R. Nycz, Warszawa 2015; Historie afektywne, polityki pamięci, red. E. Wichrowska, A. Szczepan-Wojnarska, R. Sendyka, Warszawa 2015; Migracyjna pamięć, wspólnota, tożsamość, red. R. Sendyka, R. Nycz, T. Sapota, Warszawa 2016.

${ }^{4}$ M. Jankowska, Literatura a pamięć kulturowa. Obrazoburcze rewitalizacje mitów, „Czytanie Literatury. Łódzkie Studia Literaturoznawcze” 2014, nr 3, s. 133.

${ }^{5}$ A. Assmann, Między historia a pamięcia. Antologia, red. M. Saryusz-Wolska, Warszawa 2013, s. 11.

${ }^{6}$ A. Erll, Kultura pamięci. Wprowadzenie, przeł. A. Teperek, red. M. Saryusz-Wolska, Warszawa 2018, s. 247.

${ }^{7}$ Ibidem, s. 224. 
podlega ciągłej aktualizacji, zwłaszcza przez twórców, których działalność jest dla kultury znacząca ${ }^{8}$. Można powiedzieć, że w wypadku tradycji literackiej mamy do czynienia $\mathrm{z}$ ciągłym napięciem między pamiętaniem a zapominaniem. $\mathrm{O}$ jednych twórcach się pamięta, ponieważ odcisnęli piętno, o innych się zapomina, ponieważ ich praktyka literacka nie wywarła żadnego szczególnego wpływu. W tym zaś kontekście pamięć może być fenomenem operatywnym ${ }^{9}$. W takim poniekąd sensie pisze o tym Dante Alighieri w Pieśni XIII Piekła z Boskiej Komedii ${ }^{10}$ :

Lecz chciej, kim byłeś, powiedzieć poecie,

On z niepamięci twe imię odgrzebie,

On twoją pamięć odświeży na świecie,

Gdzie ma powrócić i żyć tam na nowo.

Bardzo podobny motyw poetyckiego przywracania pamięci znajdziemy również u Lechonia, którego tendencja do przypominania ma wymiar nie tylko subiektywno-egzystencjalny, lecz także programowy — jego wiersze dotykają istotnych dla polskiej kultury faktów historycznych. Mówiąc językiem teorii literatury Lechoń jest poetą toposu, który poddaje ciągłej aktualizacji.

Lechoń jest więc poetą pamięci sensu stricto. Jego twórczość obfituje w różnego rodzaju reminiscencje dotyczące przeszłości ${ }^{11}$. Objawia się to zasadniczo na kilku poziomach poetyckiego doświadczenia. Najlepszym przykładem jest jego debiutancki tom Karmazynowy poemat, pisany w latach 1918-1919, wydany w 1920 roku $^{12}$. Tomik ten to świadectwo przeżyć wykreowanego bohatera: widoczne są tu wpływy czytanej literatury, przeżywanej historii oraz słuchanej muzyki ${ }^{13}$. Jolanta Dudek zauważa ponadto, że Karmazynowy poemat wpłynął bezpośrednio na liryczny wymiar twórczości Kazimierza Wierzyńskiego, którego tomy Wolność tragiczna oraz Kurhany, odpowiednio z 1936 i 1938 roku, są właściwie swoistym powtórzeniem obsesji tematycznych Lechonia. Nadaje to im

${ }^{8}$ K. Ratajska, Czy Lechoń $w$ Duchu na seansie kompromitowat poezję romantyczna i mitologie narodowa?, „Acta Universitatis Lodziensis. Folia Litteraria Polonica” 2001, nr 2, s. 30-33.

${ }^{9}$ A. Hutnikiewicz, Sztuka poetycka Jana Lechonia, „Zeszyty Naukowe Uniwersytetu Mikołaja Kopernika w Toruniu. Nauki Humanistyczno-Społeczne. Filologia Polska" 1960, z. 2, s. 258 259.

${ }^{10}$ D. Alighieri, Boska Komedia, przeł. J. Korsak, https://wolnelektury.pl/katalog/lektura/boska-komedia-pieklo.html [dostęp: 10.08.2019].

${ }^{11} \mathrm{Na}$ potrzeby niniejszego szkicu przyjmuję klasyfikację wyróżnioną przez Magdalenę Saryusz-Wolską za J. Assmannem i A. Assmann: 1. pamięć literatury, a zatem relacje intertekstualne między faktami literackimi; 2. pamięć w literaturze, czyli zespół istniejących w tradycji literackiej motywów pamięci; oraz literaturę jako 3. medium pamięci, co oznacza pełnienie funkcji zarówno psychicznego, jak i fizycznego nośnika pamięci. Por. M. Saryusz-Wolska, Literatura i pamięć. Uwagi wstępne, [w:] Pamięć zbiorowa i kulturowa. Wspótczesna perspektywa niemiecka, red. M. Saryusz-Wolska, Kraków 2009, s. 174-185.

12 I. Opacki, Lechoń i polskie mity, [w:] idem, Król Duch, Herostrates i codzienność. Szkice, Katowice 1997, s. 317-319.

${ }^{13}$ M. Urbańska, Inspiracje Jana Lechonia, [w:] Inspiracja, red. M. Urbańska, Łódź 2019, s. 52. 
szczególną wartość: „Tomy te podobnie jak Karmazynowy poemat Jana Lechonia mają wartość nie tylko literacką"14.

Doświadczenie poetyckie Lechonia dotyczy szeroko pojętej tradycji literackiej, w którą poeta wzorem dawnych mistrzów usiłuje się wpisać: czy to za sprawą przewartościowania, polemiki, czy też asymilacji i włączenia w określony poetycki nurt ${ }^{15}$. Można też mówić o Lechoniu w kontekście pamięci pojmowanej jednostkowo, egzystencjalnie, zwłaszcza w tych wierszach, w których porusza kwestie osobiście pojmowanej eschatologii lub refleksji nad upływem czasu i nieuchronności śmierci ${ }^{16}$. Dostrzeżono swego czasu pewien paradoks, który cechuje twórczość poetycką Lechonia. Jest ona z jednej strony mitoburcza, na przykład w wierszu Herostrates, z drugiej zaś - mitotwórcza, na przykład w wierszu Mochnacki. Podstawa likwidatora wartości kultury spiera się tu z postawą jej interpretatora i twórcy wartości ${ }^{17}$.

Dla autora Karmazynowego poematu inicjatorem „nowoczesnego” nurtu pamięciowego w poezji polskiej był Adam Mickiewicz ${ }^{18}$. K. Trybuś, potwierdzając niejako intuicję Lechonia, widzi w dokonaniach poety z Nowogródka „narodziny wspólnoty pamięci". Mickiewicz w tej optyce miał konstruktywne podejście względem podmiotu zbiorowego, umiejętnie go kształtując właśnie dzięki pamię$\mathrm{ci}^{19}$. Podobnie sądzi Irena Chyła-Szypułowa ${ }^{20}$. Co ważne w tym kontekście, sam Lechoń wiązał kunszt językowy poezji Mickiewicza z jej walorami muzycznymi: „Mickiewicz był mistrzem muzyki polskiej mowy, był Bachem jej tajemniczej pięciolinii, zdolnym jak on zestroić dźwięki w zespoły o idealnej zarazem prostocie i mądrości" 21 .

Warto zwrócić uwagę na pewne zbieżności. Łączenie motywu muzycznego z motywem pamięci pojawia się również u Mickiewicza. Doskonałym przykładem takiej operacji jest wiersz Do $M^{* * *}$, napisany najprawdopodobniej w 1823

14 J. Dudek, Liryka Kazimierza Wierzyńskiego z lat 1951-1969, Warszawa 1975, s. 58-59

15 I. Opacki, Wokót „,Karmazynowego poematu” Jana Lechonia, „Pamiętnik Literacki” 1966, z. 4, s. 439-440.

16 J. Kisielowa, Melancholia srebrna i czarna. O wierszu Toast Jana Lechonia, [w:] Liryka polska XX wieku. Analizy i interpretacje. Seria druga, Katowice 2000, s. 21.

17 T. Witkowski, Konrad i erynie — Jan Lechoń, [w:] Poeci dwudziestolecia międzywojennego. Sylwetki, t. 1, red. I. Maciejewska, Warszawa 1982, s. 442-443.

18 „Mickiewicz pokazuje nam [...], że nowość i tradycja nie są ze sobą sprzeczne, ale że przeciwnie, największe przewroty literackie czynili ci właśnie, którzy wchłonąwszy w siebie przeszłość, znaleźli przez to instynktowną miarę nowości”, J. Lechoń, Tradycja i nowość w literaturze polskiej, [w:] idem, O literaturze polskiej, Warszawa 1993, s. 14.

${ }^{19}$ K. Trybuś, Pamięć romantyzmu. Studia nie tylko z przeszłości, Poznań 2011, s. 18-19; P. Michałowski, ,Arka przymierza" $i$, osobna obecność”. Pamięć w poezji nowoczesnej, [w:] Poetologie pamięci, red. D. Śnieżko, Szczecin 2011, s. 93-94.

${ }^{20}$ I. Chyła-Szypułowa, Muzyka w poezji wieszczów, Kielce 2000, s. 61.

21 J. Lechoń, Adam Mickiewicz, [w:] idem, O literaturze polskiej..., s. 118. 
roku $^{22}$. Pamięć jest tu zjawiskiem nieokiełznanym, wymykającym się władzy człowieka:

Przecz z moich oczu! — posłucham od razu;

Przecz z mego serca! — i serce posłucha;

Przecz z mej pamięci — posłucham rozkazu,

Lecz pamięć będzie na rozkazy głucha!

Mickiewicz w pewnym sensie utożsamia pamiętanie z doświadczaniem; każdy akt ludzkiego doświadczenia znajduje swoje przedłużenie właśnie w pamięci:

Na każdym miejscu i o każdej dobie,

Gdziem z tobą płakał, gdziem się z tobą bawił,

Wszędzie i zawsze będę ja przy tobie,

Bom wszędzie cząstkę mej duszy zostawił.

W dalszej partii tekstu pojawia się charakterystyczny motyw muzyczny:

Czy zadumana w samotnej komorze

Do arfy zbliżysz nieumyślną rękę,

Przypomnisz sobie: właśnie o tej porze

Śpiewałam jemu tę samą piosenkę.

Tożsamy mechanizm muzycznej wizji przeszłości skomponował Mickiewicz w Koncercie Jankiela zamieszczonym w Panu Tadeuszu. Lechoń wykorzystuje podobną mechanikę w Mochnackim, o czym będzie jeszcze mowa.

Swoistego rodzaju operacyjny tryb „pamiętania” oraz kreowania pamięci poeta zaproponował jednak wprost ${ }^{23}$ :

Skąd Szekspir? Ot, po prostu z pamięci mej nagle

wpierw słowo, potem obraz i myśl się wynurza,

I oto wonna wyspa, wiatr dmie, hucząc w żagle,

I myślę: jaki piękny tytuł sztuki: Burza.

(Burza, 142)

Fragment ten mówi wiele o postawie artystycznej poety oraz ścieżce, jaką przejść musi myśl ludzka, by ostatecznie objawić się jako wiersz. Poeta podkreśla rolę czynnika pamięciowego. Poetycka pamięć jest w tym fragmencie źródłem działalności twórczej w ogóle. Poeta jakby „przypominał” sobie słowa, obrazy i myśli, które pragnie ułożyć w wycyzelowane wersy.

W podobny sposób ujawniają się u niego motywy muzyczne powiązane ściśle z kategorią pamięci, a także z wyłożonym explicite intertekstem:

Słyszę pieśń, co śpiewano nad moją kołyską,

widzę zioła i kwiaty nad Świtezi tonią

22 A. Mickiewicz, Wybór poezyj, t. 1, oprac. C. Zgorzelski, Wrocław 1997, s. 211-213.

${ }^{23}$ Wszystkie fragmenty poetyckie pochodzą z tomu J. Lechoń, Poezje zebrane, oprac. R. Loth, Toruń 1995. Sposób oznaczania: tytuł oraz numer strony. 
i jeszcze tylko chwila a dotknę je dłonią

(Śmierć Mickiewicza, 138)

Lechoń eksponuje kilka kwestii. Wprowadza podmiot w najbardziej podstawowy motyw pamięci istniejący w tradycji literackiej — cofnięcie do dzieciństwa. Wyposaża go w operator pamięciowy, a więc — słuch. Podmiot-dziecko jest jednocześnie podmiotem-dorosłym; słyszy pieśń-kołysankę. Słyszy ją jako wspomnienie, które towarzyszy mu przed śmiercią; poeta czyni w ten sposób z pieśni nośnik pamięci, będący jednocześnie ramą początku i końca życia człowieka.

Lechoń był reprezentantem tradycji, w której eksponowano swoisty genetyczny związek między muzyką a poezją. Pieśń jest w tym wypadku symbolicznym spoiwem między dwoma porządkami słyszenia - słyszenia melodii oraz słyszenia poezji. Muzyka, co postaram się udowodnić, mogła mieć dla Lechonia charakter metafizyczny. Sens tego rozpoznania opisał niegdyś Marian Przełęcki: „Przedmiotem metafizycznych wartościowań są z reguły całości takie, jak świat, człowiek czy historia, a wartości, które się przypisuje tym całościom, obejmować mogą wartości różnego typu (moralne, estetyczne, »numiniczne«) i różnej jakości (pozytywne i negatywne)"24. Oznacza to, że porządek metafizyczny to jednocześnie porządek wartości: jest to sfera uświęcona i uświęcana zarazem. Muzyka w takim kontekście staje się niejako polem określanej przez poetę aksjologii.

\section{Muzyka, muzyczność, audialność}

Andrzej Hejmej wyróżnił trzy podstawowe typy muzyczności literatury ${ }^{25}$ : Muzyczność I, a więc szczególną organizację brzmieniowo-dźwiękową dzieła literackiego; Muzyczność II lub inaczej: tematyzację muzyki w literaturze; oraz Muzyczność III, czyli tak zwane intersemiotyczne nawiązania formalnostrukturalne między obiema sztukami. Ta typologia ma swoje mankamenty, niemniej jednak jest najbardziej operatywna i reprezentatywna dla współczesnych badań muzyczno-literackich. Na jej podstawie przedstawiony zostanie ogólny plan teoretyczny, który w następstwie przysłuży się bardziej szczegółowej analizie.

Motywy muzyczne w poezji Lechonia są zauważane i opisywane od wielu lat, o czym świadczy już nader pokaźna biblioteka pism. Warto jednak zasygnalizować, że $\mathrm{w}$ badaniach $\mathrm{z}$ ostatnich lat dochodzi do przesunięcia dominanty poznawczej w samym przedmiocie badań: muzyka staje się elementem szerszego zbioru, jakim jest uniwersum dźwięku. Rozwijające się prężnie studia nad dźwiękiem (sound studies), resp. antropologia dźwięku lub audioantropologia, zaczynają przenikać do badań literackich, otwierając nowe, ciekawe perspektywy

${ }^{24}$ M. Przełęcki, Metafizyczna treść muzyki, „Archiwum Historii Filozofii i Myśli Społecznej” 42, 1997, s. 172.

25 A. Hejmej, Muzyczność dzieła literackiego, Toruń 2012, s. 63-76. 
badawcze ${ }^{26}$. W niniejszym artykule problematyka audialna nie będzie jednakże obszerniej analizowana.

\section{A. Muzyka w życiu Lechonia}

Krótki przegląd Lechoniowych „muzyczności” należy zacząć od krótkiej charakterystyki biograficznej. Muzyka odgrywała w życiu poety relatywnie istotną rolę. Wanda Łukszo-Nowakowska przekonuje, że młody Leszek uczył się gry na fortepianie i śpiewu. Jest podobno autorem kompozycji muzycznej — pieśni do wiersza Paula Verlaine'a Chanson d'automne ${ }^{27}$. Dorosły natomiast Lechoń był autorem licznych muzycznych recenzji. Przyjaźnił się z kilkoma znanymi muzykami, między innymi z Karolem Szymanowskim, Wandą Landowską czy Arturem Rubinsteinem. Chadzał często na koncerty, żywo opisywał grę tak wybitnych pianistów, jak chociażby Vladimir Horovitz, Rudolf Serkin czy wspominany już Rubinstein $^{28}$.

Wiele o Lechoniu jako artyście mówi jego gust muzyczny. Niejednokrotnie przywoływano konserwatyzm poety, jego staroświeckość, przywiązanie do form relatywnie kanonicznych, anachronizm poetycki ${ }^{29}$. Muzyczne upodobania jedynie utwierdzają w podobnym przekonaniu. Lechoń cenił muzykę Johanna Sebastiana Bacha, Wolfganga Amadeusza Mozarta, Josepha Haydna, Franza Schuberta, Johannesa Brahmsa i Francisa Poulenca ${ }^{30}$. Gust muzyczny Lechonia wyraźnie korespondował $\mathrm{z}$ jego upodobaniami estetycznymi ${ }^{31}$. Albowiem jeśli to zestawienie uprościć, żeby znaleźć w nim wspólny mianownik, trzeba powiedzieć, że każdy $\mathrm{z}$ wymienionych kompozytorów w jakiejś mierze związany jest $\mathrm{z}$,apollińskim” nurtem sztuki. Można określić Lechonia tradycjonalistą ${ }^{32}$, co wyjaśnia także brak szczególnego zrozumienia, jaki skamandryta okazywał awangardowej muzyce swoich czasów i jednego z jej ojców-założycieli - Arnolda Schönberga ${ }^{33}$. Interesował go najbardziej Bach, absolutny geniusz pieczołowitości i arcymistrz chyba

${ }^{26}$ Najlepszym przykładem są dwa artykuły wspominanej już Eweliny Radion: Audiosfera „Karmazynowego poematu” Jana Lechonia oraz Percepcja wrażeń akustycznych w wierszu Mochnacki Jana Lechonia.

27 W. Łukszo-Nowakowska, Jan Lechoń. Zarys życia i twórczości, Warszawa 1996, s. 62.

28 J. Skarbowski, Muzyczna dusza Jana Lechonia, [w:] idem, Literacki koncert polski, Rzeszów 1997, s. 124-126.

${ }^{29}$ M. Urbanowski, Romantyzm w literaturze dwudziestolecia międzywojennego (przechadzka historycznoliteracka), [w:] Loci (non) communes. Prace ofiarowane Profesor Marii Korytowskiej, red. O. Płaszczewska, M. Siwiec, Kraków 2017, s. 156.

${ }^{30}$ A. Hejmej, op. cit., s. 126-127.

${ }^{31}$ A. Nawarecki, O rzeczach, [w:] idem, Parafernalia. O rzeczach i marzeniach, Katowice 2014, s. 66, 69.

32 W 1958 roku wspominał Jan Brzękowski: „Lechoń tkwi mocno w epoce poprzedzającej, jego klasycyzm ma tchnienie romantyczne, cechuje go koturnowość, patos i skłonność do pseudogłębokich point filozoficznych". Por. J. Brzękowski, Awangarda. Szkic historyczno-teoretyczny, [w:] idem, Wyobraźnia wyzwolona. Szkice i wspomnienia, Kraków 1976, s. 100-101.

33 J. Skarbowski, op. cit., s. 127. 
najbardziej matematycznej z wszystkich muzycznych form - fugi ${ }^{34}, \mathrm{z}$ drugiej Mozart i Haydn ${ }^{35}$, przedstawiciele wiedeńskiego klasycyzmu, muzyki — zwłaszcza w wypadku Haydna - bardzo zracjonalizowanej, w swej naturze prostej, w zamyśle i wykonaniu doskonałej. Dalej pojawia się Schubert — niejako łącznik między epoką klasycyzmu i romantyzmu. Brahms to z kolei twórca muzyki romantycznej, lecz sam nie romantyk, przywiązany bardzo do klasycznych, uporządkowanych form wyrazu muzycznego ${ }^{36}$. Poulenc to przedstawiciel między innymi dwudziestowiecznego neoklasycyzmu francuskiego. W tym ostatnim przypadku sympatia może wiązać się także z wątkiem osobistym. Poulenc napisał dla polskiej klawesynistki Wandy Landowskiej utwór Concert champêtre na klawesyn i orkiestrę ${ }^{37}$. Lechoń bardzo cenił Landowską, z którą osobiście się przyjaźnił; poświęcił jej wiersz Sarabanda dla Wandy Landowskiej. Ulubionym kompozytorem poety, co mało zaskakujące, był Fryderyk Chopin ${ }^{38}$.

$\mathrm{Z}$ tych danych można wysnuć kilka wniosków. Lechoniowi obca była estetyka awangardowa zarówno w poezji, jak i w muzyce. Nie akceptował z jakiegoś powodu załamania się tradycyjnych sposobów operowania dźwiękiem i komponowania form. Nie doceniał walorów systemów atonalnych czy konstruktywistycznej maniery kompozytorów z tak zwanej nowej szkoły wiedeńskiej. Nie akceptował ani dodekafonii, ani politonalności, przypuszczalnie również nowych języków harmonicznych i rytmicznych.

\section{B. Muzyczność jako kategoria estetyczno-egzystencjalna}

Lechoń nie stosuje na dużą skalę typowej dla symbolizmu i części nowej awangardy muzyczności I. Ośrodkiem walorów muzycznych i dźwiękowych jest w jego poezji rytm i rym. Dystansuje się ponadto od pierwiastka lirycznego, obierając najczęściej pozycje epickie, narracyjne, dlatego też unika muzyczności III. Podstawową kategorią interpretacyjną w wypadku Lechonia będzie muzyczność II. Jest ona najbardziej operatywna, koresponduje bowiem w sposób naturalny z zewnętrznymi wobec sobie kategoriami. Żadna z tych koncepcji nie do końca nadaje się jednak do opisu sytuacji, w której muzyka staje się dla poety rodzajem kategorii estetycznej współodpowiedzialnej za proceder twórczy. Najłatwiej uchwycić jej sens w osobistych notatkach poety. Podobny fenomen nie

${ }^{34}$ B. Pociej, Bach - muzyka i wielkość, Kraków 1972, s. 18-20.

${ }^{35}$ Ch. Rosen, The Classical Style. Haydn, Mozart, Beethoven, New York-London 1997, s. 20 24; N. Elias, Mozart. Portret geniusza, oprac. M. Schröter, przeł. B. Baran, Warszawa 2006, s. 47.

36 A. Einstein, Muzyka w epoce romantyzmu, przeł. M. i S. Jarocińscy, Kraków 1983, s. 160.

${ }^{37}$ B. Schaeffer, Dzieje muzyki, Warszawa 1983, s. 366.

38 Wpływ muzyki Chopina na twórczość literacką w dwudziestoleciu międzywojennym był bardzo silny. Poucza o tym książka Józefa Opalskiego Chopin i Szymanowski w literaturze dwudziestolecia międzywojennego, Kraków 1980, passim. Lechoń poświęcił Chopinowi kilka wierszy, na przykład przez motyw walca w Pani Słowackiej, wiersz B-moll - aluzję do trzeciej części Sonaty b-moll op. 35, znanej jako Marche funebre, oraz wiersz Skowronek, z motywem ,ptaszka z Żelazowej Woli”. 
ma jeszcze swoistej nazwy, choć roboczo można by go określić czymś w rodzaju Muzyczności IV.

Próbką takiej konceptualizacji doświadczenia muzycznego są zapiski Lechonia w jego Dzienniku. Autor w formie krótkich codziennych wpisów relacjonuje prace nad wierszem poświęconym Wandzie Landowskiej. Poeta chciał napisać dzieło łączące walory muzyczne i literackie, a więc w jakimś sensie intersemiotyczne. Wiersz-poemat miał się stać utworem o silnym muzycznym nacechowaniu („,To jest ten wiersz: Do Wandy Landowskiej, który musi mieć muzykę godną muzyki”39), zmiennych rytmach (,Wiersz ten powinien to być większy poemat — o zmiennych rytmach, czego dotychczas nie robiłem" ${ }^{40}$ ) oraz o odpowiedniej melodii. Poeta ponadto paradoksalnie kategoryzuje „muzykę” jako element jednocześnie opisowy i waloryzujący:

To, co dziś napisałem, ma ładną obrazowość, ale jeszcze za dużo logicznych powiązań, za mało asocjacji. I ładna muzyka, ale znana. [...] Za to całą noc — budziła mnie muzyka i wewnętrzne rymy wiersza Do Wandy Landowskiej ${ }^{41}$.

Celem twórcy byłoby w tym wypadku, jak sam się wyraził: „,naprawdę dać coś z najwyższej muzyki, pojętej tak po prostu, ale i tak wysoko, jak ją pojmuje Wanda”. Lechoń pragnie „przełożyć” doświadczenia muzyczne wprost na doświadczenie poetyckie. $Z$ jednej strony poeta pragnie uczynić swój poemat obrazem „własnej muzyki”, a więc bezpośredniego audialnego doświadczenia, z drugiej zaś — zadość uczynić doświadczeniu muzycznemu Landowskiej. Bardzo ważnym elementem $w$ procederze tworzenia wiersza była jego językowa reprezentacja dźwiękowa, a więc coś w rodzaju eurytmii ${ }^{42}$, którą Lechoń słyszał w słowach:

Całe rano nad jedną zwrotką. Nie ma w niej takiej, jakiej chciałbym, dalekiej metafory. Ale brzmi dobrze i coś, myślę, sensownego wyraża ${ }^{43}$. [...]

Jedna zwrotka, ale niedobra. Bez muzyki, bez świeżości. Może dobiorę się wreszcie w tym wierszu do właściwego tonu; wtenczas wszystko to będzie można zmienić ${ }^{44}$.

Lechoń ciągle myśli kategoriami muzyczno-dźwiękowymi. Do wiersza według jego przepisu należy dobrać odpowiedni ton, wszak dopiero wtedy muzyka wiersza zyska jakikolwiek ontologiczny status. Poeta często podkreśla, że coś „ma muzykę” lub „nie ma muzyki”. Jest to znamienne, dlatego że doświadczenie muzyczne, czyli w tym wypadku słuchanie gry Landowskiej, musi zostać jakoś wyładowane i zaprzęgnięte w formułę poetycką. Lechoń konsekwentnie uznaje,

39 J. Lechoń, Dziennik, t. 1, Warszawa 1992, s. 189.

${ }^{40}$ Ibidem.

${ }^{41}$ Ibidem, s. $190-191$.

42 „Symetria dotyczyła piękna absolutnego, eurytmia - piękna dla oczu lub ucha”. Por. W. Tatarkiewicz, Skupienie i marzenie. Studia z zakresu estetyki, Kraków 1951, s. 24.

43 J. Lechoń, Dziennik, t. 1, s. 194.

44 Ibidem, s. 213. 
że wiersz będzie udany dopiero wtedy, gdy osiągnie optymalną „zażyłość” z materiałem muzycznym.

\section{Muzyka i pamięć}

Przyjrzyjmy się jednemu z najbardziej znanych wierszy Lechonia pt. Herostrates z tomu Karmazynowy poemat (1920). Pojawiają się w nim motywy, między innymi muzyczne, częściowo obecne w późniejszej twórczości poety ${ }^{45}$ :

Ja nie chcę nic innego, niech jeno mi płacze

Jesiennych wiatrów g ę d ź b a w półnagich badylach;

A latem niech się słońce przygląda w motylach,

A wiosną — niechaj w i o s n ę, nie Polskę zobaczę.

$[\ldots]$

I chciałbym raz zobaczyć, gdy przeszłość wyżeniem,

Czy wszystko w pył rozkruszę, czy... Polskę obudzę.

(Herostrates, 25)

Pojawia się w powyższym fragmencie wyraz gędźba; jest to staropolskie słowo oznaczające „muzykę”, ,instrument muzyczny”, ,granie na instrumencie”46. Widać tu jeszcze wyraźne wpływy estetyki młodopolskiej ${ }^{47}$. Ważniejszy jest jednak słynny fragment dotyczący wiosny. Koresponduje on z motywem wiosny z wiersza Mochnacki z tego samego tomiku. Owo arcydzieło poezji opisowej po raz pierwszy na taką skalę pokazuje, jak fenomenalną wyobraźnię muzyczną miał Lechoń:

Mochnacki jak trup blady siadł przy k la w i k o r d z i e

I z wolna jął próbować a $\mathrm{k}$ ord po a kordzie.

$[\ldots]$

On wie, że okop hardy w tej przepaści rośnie,

Więc skrył się za okopem i zagra o w i o śn i e.

$[\ldots]$

Rozpędził białe palce świergotem w wiolinie

I mały, smutny strumień spod ręki mu płynie.

Raz w raz rosa po białej pryska klawiaturze

I raz po raz w wiolinie kwitną polne róże.

$[\ldots]$

Coraz niżej i niżej, uschną, w bas się zmienią!

$[\ldots]$

Głupio, sennie, bezmyślnie kręci się i kręci.

Jakieś myśli chce straszne wy zucić z pamięci.

45 I. Opacki, Król-Duch, Herostrates i Juliusz. Trzy spotkania liryki ze Stowackim, „Pamiętnik Literacki" 1981, z. 3, s. 209-210.

46 Z. Gloger, Encyklopedia staropolska, t. 2, Warszawa 1901, s. 183.

${ }^{47}$ Innym przykładem takiej poetyki jest młodzieńczy wiersz Lechonia Zapłakat wiatr jesienny, opublikowany w tomiku Po różnych ścieżkach w 1914 roku: „Ktoś płacze. Nie. To wicher wionął po ogrodzie. / Ktoś załkał. Nie. To krzewy zaszumiały z cicha” (PZ 460). 


\section{$[\ldots]$}

I znów wraca ku górze załzawionym dźwiękiem -

W mazurze - nie - w mazurku idą wszystkie pary,

By całą klawiaturę owinąć w sztandary.

(Mochnacki, 36)

Pierwsza informacja to dobór instrumentu muzycznego. W tym wypadku Lechoń albo popełnił błąd, stosując anachronizm, albo zastosował konwencjonalny zabieg kompozycyjny: użycie wyrazu tylko w celu osiągnięcia rymu ${ }^{48}$. W rzeczywistości obecność klawikordu na salach koncertowych jest wykluczona z powodów technicznych - jest wszak instrumentem bardzo cichym ${ }^{49}$. Ciekawym zabiegiem jest wewnętrzna dramatyzacja wiersza: podział na partie „wiolinowe” i „basowe”. Pojawia się w tym kontekście wspomniany motyw wiosny. Tym razem służy bezpośrednio wykreowaniu muzycznej metaforyki. Cel tego zabiegu jest jasno wyrażony: „aby myśli straszne wyrzucić z pamięci”. Motywika pamięciowa ma tutaj podwójną naturę: po pierwsze, jest to pamięć kreowanej poetycko postaci odgrywającej koncert; po drugie, pamięć obecna jest na poziomie narracji. W partiach metaforyzujących wprowadza poeta opozycję muzyki natury i muzyki kultury, które w trakcie gry pianisty wzajemnie się przenikają i uzupełniają. Jest to motyw także i później replikowany przez Lechonia.

Mochnacki jest przykładem poetyckiego opisu występu muzycznego, stoi w tej samej jednej linii rozwojowej co Koncert Jankiela Mickiewicza czy Koncert Chopina Artura Oppmana ${ }^{50}$. Ireneusz Opacki, dokonując podobnego porównania, zwrócił uwagę na zupełnie inne układy tych koncertów i odmienny tryb traktowania tradycji mitycznej oraz historycznej. Zauważył, że każdy z wymienionych koncertów reprezentuje jakiś stosunek autorów do pojęcia polskości ${ }^{51}$. I co najistotniejsze — każdy z koncertów to jednocześnie ewokowana przez motyw gry na instrumencie muzycznym galeria polskich mitów narodowych ${ }^{52}$.

Kolejnym świadectwem muzycznej świadomości Lechonia był wiersz Pitsudski (PZ 39), w którym autor posłużył się obecnym w polskiej literaturze motywem balu (na przykład Bal u Senatora w Dziadach części III Mickiewicza, motyw za-

${ }^{48}$ Kwestia ta była już poruszana przez badaczy. Najpierw zwrócił na nią uwagę Adam Czerniawski, twierdząc, że należy to traktować jako licentia poetica. Por. A. Czerniawski, Sarabanda Lechonia, [w:] idem, Liryka i druk. Szkice i eseje, Londyn 1972, s. 93-94. Po raz kolejny problemowi klawikordu przyjrzał się Jerzy Wiśniewski, udowadniając jednoznacznie, że wyraz ten jest użyty błędnie, jeśli do badania zastosować kryterium historyczne lub muzykologiczne. Jedyne, co sensownie może thumaczyć wybór Lechonia, to celowy zabieg archaizacyjny, stworzenie określonego kolorytu całości obrazu. Por. J. Wiśniewski, Czy Maurycy Mochnacki koncertowat, grając na klawikordzie? Uwagi na marginesie wiersza Jana Lechonia, „Acta Universitatis Lodziensis. Folia Litteraria Polonica” 2001, nr 2, s. 45-46.

49 C. Sachs, Historia instrumentów muzycznych, przeł. S. Olędzki, Kraków 1989, s. 310-311.

${ }^{50}$ R. Loth, Wstęp, [w:] J. Lechoń, Poezje, oprac. R. Loth, Wrocław 1990, s. XLI-XLII.

${ }^{51}$ I. Opacki, Dramat narodowej wyobraźni. Wokót „, Karmazynowego poematu” Jana Lechonia, [w:] idem, Król Duch..., s. 68-73.

52 Ibidem, s. 71. 
bawy weselnej w Weselu Wyspiańskiego, a także w kulturze dwudziestolecia: Bal u Senatora Lechonia, Bal w operze Tuwima, Bal u Salomona Gałczyńskiego ${ }^{53}$ :

I gdzieś kończy muzyką jakiś bal spóźniony. [...]

I mazur, biały mazur w ogłupiałej sali.

$[\ldots]$

Dla siebie, nie dla gości, gra jeszcze muzyka

Menuetem się cichym wiolonczela żali.

Pojawia się w tym utworze postać Aleksandra Skriabina. Ewokuje ona ciekawą literacką rewelację, którą nazwać by można motywem dysonansu:
A w klarnet, flet, skrzypce w ukłony margrabin
Czerwoną, rozwichrzoną w pada nutą Skriabin.
Drze ciszę dysonansem, wali wokiennice,
Muzykę wyprowadza przed dom, na ulice,
Na place, rozkrzyczane w potępieńcze ryki
I rzuca w twarzakordom zgłodniałe okrzyki,
Na ziemię je obalił i kopie z rozpaczą:
Otworzyć wszystkie okna! Niech ludzie zobaczą!

Jest to figura bardzo ważna. Jej obecność udowadnia, że Lechoń był świadomy zmian, jakie zachodziły ówczesnej w muzyce. Skriabin był tym kompozytorem, który na stałe wyemancypował akord dysonansowy. Sprawił, że zyskał on te same prawa, co akordy konsonansowe. Ostatecznie rozbił w ten sposób logikę ówczesnego systemu harmonicznego. Dlatego u Lechonia Skriabin „drze ciszę dysonansem”. Trudno ocenić, czy podmiot wiersza wypowiada tę kwestię aprobatywnie. Jest to tym niemniej ciekawy przykład zwarcia tradycji literackiej i muzycznej.

Następny wiersz, a więc Lutnia po Bekwarku (PZ 69), prezentuje oryginalną figurę muzyka-wirtuoza zestawioną z figurą poety-wirtuoza. Pojawia się po raz kolejny motyw typowy dla Lechonia — zestawienie muzyki natury i muzyki kultury i ich wzajemne przenikanie:

Już zamilkły s a rabanda i włoska pawana,

Wzeszły gwiazdy na niebo, jest cisza dokolna.

I wtedy Jan cię dotknął. I pod ręką Jana

Zadrgałaś jak plusk rzeki, jak muzyka polna.

Tytułowa postać węgierskiego kompozytora i lutnisty Valentina Bakfarka pojawia się już w poezji Jana Kochanowskiego; konkretnie zaś we fraszkach $O$ gospodyniej oraz $O$ Bekwarku. Roman Loth twierdzi, że intertekst Lechonia odnosi się do tego pierwszego utworu ${ }^{54}$.

53 Rozbudowaną aluzję do Wyspiańskiego widzi w tym wierszu Gustaw Ostasz: „Muzyka i taniec w Piłsudskim nie są, co prawda, identyczne z muzyką i tańcem u Wyspiańskiego. Pełnią jednak funkcje zbliżone”, idem, W cieniu „Herostratesa”, Rzeszów 1994, s. 48.

${ }^{54}$ R. Loth, op. cit., s. 45. 
Lechoń w dużym stopniu przekształca tradycję. Dla skamandryty ten zmysł reorganizacji jest bardzo charakterystyczny. U Kochanowskiego motyw Bakfarka ma sens anegdotyczny, służy do wykreowania zabawnej erotycznej puenty we fraszce. Lechoń kładzie natomiast nacisk na atrybuty genialnego muzyka: lutnię oraz umiejętność gry na tejże. Wykorzystując zaś figurę metonimii, postać Bakfarka scharakteryzował poeta tak: „Na starej ławce leży lutnia po Bekwarku / Świerszcz zagrał, i na lutni drgnęła struna czysta”. Kończy wszystko motyw pamięci sprzężony z przestrzenią audialną, która okazuje się jego przyczyną:

Stoję w oknie i słucham, jak płynie muzyka.

Myślałem, że zapomnę. Pamiętam na nowo.

\section{Aria z Kurantem Moniuszki}

Osobny podrozdział chciałbym poświęcić muzycznym motywom poetyckim związanym bezpośrednio z twórczością Stanisława Moniuszki. Ocena jego działalności kompozytorskiej ma charakter sinusoidalny. Dla jednych był muzycznym odpowiednikiem Adama Mickiewicza ${ }^{55}$, dla innych „lirnikiem wioskowym”, „małym romantykiem"56. Moniuszko jest tym wszelako kompozytorem, który wchodził w ścisłe interakcje ze światem literackim. Wiele mówiono i pisano o literackich inspiracjach w muzyce Chopina, ale kompozytor z Żelazowej Woli pod tym względem nie mógł się z Moniuszką w najmniejszym stopniu równać ${ }^{57}$. Autor Halki bardzo często i realnie wiązał ze sobą owe dwa światy - muzyczny i literacki. Jak przekonuje Irena Poniatowska: „Wystarczą jednak dwie wielkie opery - Halka, Straszny dwór i kilkanaście doskonałych pieśni, by Moniuszkę wynieść na piedestał najwybitniejszego przedstawiciela muzyki wokalnej dziewiętnastego wieku"58.

Mimo powszechnego uznania muzykę Moniuszki zarówno w okresie Młodej Polski, jak i w dwudziestoleciu szczególnie kontestowano - jako tradycjonalistyczną i nienowoczesną ${ }^{59}$. W tej sytuacji gest Lechonia, czyli tom poetycki Aria z kurantem, opublikowany przez poetę w 1945 roku, jest nie tylko najbardziej reprezentatywnym zbiorem „muzyczności” Lechoniowych, ale i swoistym spojrzeniem w głąb tradycji muzycznej. Oto przykłady łączenia motywów muzycznych i motywów pamięci:

Wszystkie słowa podniosłe, któreś znał ze szkoły,

Muzyka starych pieśni, wolności anioły...

(Legenda, 96)

55 W. Fabry, Moniuszko. Powieść biograficzna, Warszawa 1938, s. 7-8.

${ }^{56}$ I. Poniatowska, Historia muzyki polskiej, t. 5. Romantyzm, cz. 2A. Twórczość muzyczna $w$ drugiej połowie XIX wieku, Warszawa 2010, s. 82.

57 M. Dziadek, Podróż przez dźwięki. Śladami Stanisława Moniuszki, Kraków 2020, s. 73-74.

58 I. Poniatowska, op. cit., s. 85.

59 Ibidem, s. 82. 
Z odmętu niepamięci jakiś powiew żenie

Dźwięk słów na pozór błahych jak pożółkłe wstążki

Których teraz dopiero rozumiesz znaczenie,

Jak za wcześnie czytanej bardzo mądrej książki.

(Jabłka i astry, 114)

Widać wyraźnie, jak poeta tworzy logiczne continuum między motywem pamięci a muzyką. Najważniejszy okazuje się jednak wiersz tytułowy ${ }^{60}$, oto kluczowe fragmenty:

Smutek mnie taki chwycił, że zda się, aż skomli,

Ani przed kim się żalić, kto wie, kiedy minie

$[\ldots]$

Cóż znajdę, jeśli wyjdę takiego wieczoru?

Tu wszyscy przecież obcy i każdy gdzieś śpieszy.

Ach, żadna mnie muzyka dzisiaj nie pocieszy,

Chyba Aria z kurantem ze Strasznego dworu.

(Aria z kurantem, 95)

Jest to jedyny utwór Lechonia, w którym obecny jest bezpośredni intertekstualny interpretant, a więc ten element tekstu, który ma charakter zarówno wewnętrzny, jak i zewnętrzny ${ }^{61}$. O funkcji muzyki dowiadujemy się wprost: chodzi o pocieszanie. Motyw pamięci jest w tym tomie jeszcze bardziej spotęgowany, albowiem poecie towarzyszyła świadomość, że najprawdopodobniej już nigdy nie wróci do kraju ${ }^{62}$.

Tomik Lechonia jest bardzo oryginalnym sposobem na ukazanie relacji intertekstualnej między poezją a muzyką oraz poezją a dziełem dramatycznym, jakim jest operowe libretto. Aria z kurantem to rodzaj intertekstualnej konstrukcji. Lechoń odsyła czytelnika bezpośrednio do intertekstu, którym jest fragment libretta autorstwa Jana Chęcińskiego ${ }^{63}$. To na jego podstawie Stanisław Moniuszko w latach 1862-1864 skomponował operę Straszny dwór:

(Zegar bije pótnoc)

Cóż to jest?

${ }^{60}$ Lechoń napisał kilka wierszy o tytułach zawierających słowo „aria”. Są to wiersze satyryczne, zamieszczane w tak zwanych szopkach politycznych „Cyrulika Warszawskiego”, na przykład Aria Artura Śliwińskiego, Aria Ireny Solskiej, Aria Stanisława Strońskiego, Aria Stefana Przeździeckiego.

${ }^{61}$ Aleksandra Reimann określa ten element tekstu ,intencjonalnym sygnałem intertekstualności”; por. eadem, Muzyczny styl odbioru tekstów literackich, Poznań 2013, s. 22.

62 Joanna Kisielowa zauważa, że rzeczywistość wykreowana przez Lechonia ma charakter zamknięty, dlatego też człowiek w nim zamknięty „ucieka w przeszłość, zamyka się w pokoju, który wypełnia przestrzeń lektury i muzyki”. Natomiast życie podmiotu „podporządkowane zostaje rytmowi powtarzanych wzruszeń - aria Moniuszki, wiersze Syrokomli...”. Por. eadem, Retoryka i melancholia. O poezji Jana Lechonia, Katowice 2001, s. 190.

${ }^{63}$ J. Chęciński, Straszny dwór. Opera w 4ch aktach, z którego pierwszy w dwóch odsłonach, Warszawa 1865, s. 65-66. 
Maciej mówił, że od lat tysiąca,

Chyba dusza wracająca

Spoza grobu, dla pokuty

Wprowadza w obrót ten zegar popsuty.

Zegar skończywszy bić, gra poloneza.

Przestał bić, a teraz gra.

(Stucha)

Boże mój! melodia ta,

Jakież chwile przypomina!

Niegdyś mój ojciec, w rodzinnym kole naszem

Mnie lub Zbigniewa, starszego syna,

Ucząc drewnianym władać pałaszem,

Tak często nucił ten sarmacki śpiew!

(Aria Stefana)

Lechoń odwołuje się do arii Moniuszki, której zarówno melodyka, jak i tekst są próbą wyrażenia treści nostalgicznych i emocjonalnie nacechowanych. Co więcej, zachodzi w tym kontekście możliwość wytyczenia kolejnej linii pamięci, albowiem Moniuszko również dokonuje artystycznej reminiscencji, wystosowując melodyczną aluzję w kadencji ośmiotaktowego poloneza, który odgrywany jest przed słowami: „Boże mój, melodia ta”. Organizuje zatem przestrzeń dzieła w taki sposób, że melodia koresponduje nie tylko z tekstem libretta, lecz także $\mathrm{z}$ tradycją kształtowania melodyki. Kadencja kurantowego poloneza wprost koresponduje ze znanym Polonezem a-moll Michała Kleofasa Ogińskiego, popularnie tytułowanym Pożegnanie ojczyzny. Utwory te różni co prawda tonacja: g-moll u Moniuszki, a-moll u Ogińskiego; jednakże podobieństwo fraz melodycznych w kadencji jest zauważalne ${ }^{64}$ :

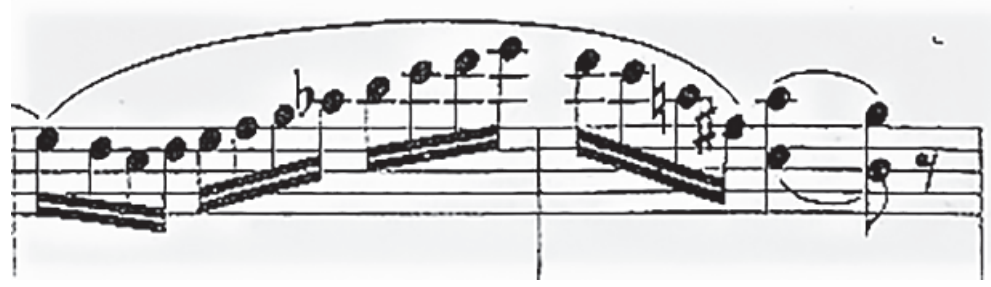

Przykład 1. Kadencja poloneza Arii z kurantem S. Moniuszki

${ }^{64}$ Przykłady nutowe pochodzą z następujących wydań: S. Moniuszko, Straszny Dwór. Opera w 4 aktach, oprac. J. Lefeld, Warszawa 1937, s. 245-251; M.K. Ogiński, Lesadieux à la patrie. Polonaise no. 12, wydał Gebethner i Wolff, Warszawa 1900, s. 1-4. 


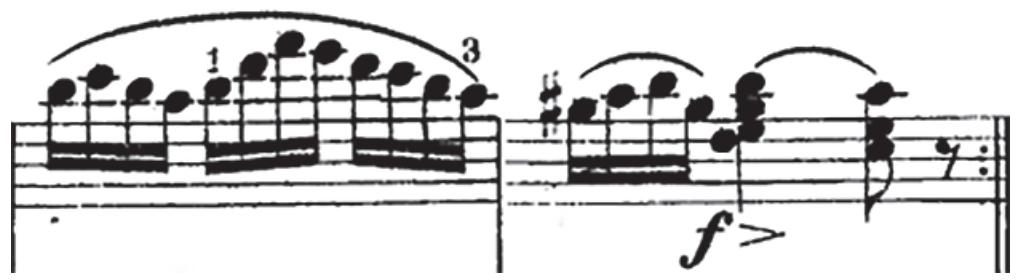

Przykład 2. Kadencja Poloneza a-moll M.K. Ogińskiego

Nawiązuje w ten sposób Moniuszko do wypracowanego i stworzonego przez Ogińskiego modelu poloneza artystycznego, który przestał być tańcem użytkowym, a stał się dziełem artystycznym i tak zwanym stylizowanym. Warto ponadto zauważyć, że Moniuszko w późnych latach pięćdziesiątych XIX wieku sam zaaranżował na fortepian sześć polonezów Ogińskiego, dedykując ową edycję Franciszkowi Lisztowi ${ }^{65}$.

Tworzy się tym samym oś chronologiczna: w 1794 roku Ogiński pisze Poloneza a-moll. Kontekst historyczny, który temu towarzyszy, jest jasny: upadek Pierwszej Rzeczypospolitej. W 1865 roku Moniuszko wystawia po raz pierwszy operę Straszny dwór, będącą bezpośrednią reakcją na porażkę w powstaniu styczniowym. Inspiruje się Mickiewiczowskim Panem Tadeuszem, pisząc „ku pokrzepieniu serc"66. W 1945 roku Jan Lechoń pisze tom Aria z kurantem; kontekstem historycznym zbioru jest największy kataklizm wojenny w dziejach. Być może to tylko koincydencja, dzieło przypadku, a być może coś zaplanowanego, jakaś złożona pamięciowa konstrukcja, zapewniająca polskiej kulturze ciągłość czasowo-przestrzenną, zwłaszcza w wymiarze symbolicznym.

\section{Podsumowanie}

Motywika muzyczna w poezji Lechonia nie ma charakteru rewolucyjnego, jak na przykład w poezji futurystycznej. U skamandryty materia ta jest ściśle podporządkowana nadrzędnej problematyce jego poezji. Ujawnia się o tyle, o ile pełni jakąś znaczącą funkcję w większej całości. Niemniej same muzyczne motywy są tak samodzielne, że można o nich mówić jako o przejawie wyobraźni i talentu poetyckiego.

Wplatanie tych licznych wątków tematycznych w ogólne uniwersum poetyckie było u Lechonia przemyślane. Nie było w tym wiele z typowej dla poezji modernistycznej tendencji do podbijania nastroju czynnikami wobec poezji zewnętrznymi. I co najważniejsze w kontekście paradygmatu przyjętego w tym

${ }^{65}$ Por. M.K. Ogiński, Six polonaises du Prince Michel Ogiński. Transcrites pour le piano par Stanislas Moniuszko, Wilno 1859.

${ }^{66}$ W. Rudziński, Moniuszko, Kraków 1972, s. 194-197. 
artykule: muzyczne motywy to materiał łączący się bezpośrednio z motywiką pamięci. Lechoń transponuje kategorię pamięci na porządek intersemiotyczny: to zarówno pamięć w poezji, jak i pamięć w muzyce.

\section{Bibliografia}

Alighieri D., Boska Komedia, przeł. J. Korsak, https://wolnelektury.pl/katalog/lektura/ boska-komedia-pieklo.html [dostęp: 10.08.2019].

Assmann A., Między historią a pamięcią. Antologia, red. M. Saryusz-Wolska, Warszawa 2013.

Brzękowski J., Awangarda. Szkic historyczno-teoretyczny, [w:] idem, Wyobraźnia wyzwolona. Szkice i wspomnienia, Kraków 1976.

Chęciński J., Straszny dwór. Opera w 4ch aktach, z którego pierwszy w dwóch odstonach, Warszawa 1865.

Chyła-Szypułowa I., Muzyka w poezji wieszczów, Kielce 2000.

Czerniawski A., Sarabanda Lechonia, [w:] idem, Liryka i druk. Szkice i eseje, Londyn 1972.

Dudek J., Liryka Kazimierza Wierzyńskiego z lat 1951-1969, Warszawa 1975.

Dziadek M., Podróż przez dźwięki. Śladami Stanisława Moniuszki, Kraków 2020.

Einstein A., Muzyka w epoce romantyzmu, przeł. M. i S. Jarocińscy, Kraków 1983.

Elias N., Mozart. Portret geniusza, oprac. M. Schröter, przeł. B. Baran, Warszawa 2006.

Erll A., Kultura pamięci. Wprowadzenie, przeł. A. Teperek, red. M. Saryusz-Wolska, Warszawa 2018.

Fabry W., Moniuszko. Powieść biograficzna, Warszawa 1938.

Gloger Z., Encyklopedia staropolska, t. 2, Warszawa 1901.

Hejmej A., Muzyczność dzieła literackiego, Toruń 2012.

Hutnikiewicz A., Sztuka poetycka Jana Lechonia, „Zeszyty Naukowe Uniwersytetu Mikołaja Kopernika w Toruniu. Nauki Humanistyczno-Społeczne. Filologia Polska” 1960, z. 2.

Jankowska M., Literatura a pamięć kulturowa. Obrazoburcze rewitalizacje mitów, „Czytanie Literatury. Łódzkie Studia Literaturoznawcze" 2014, nr 3.

Kisielowa J., Melancholia srebrna i czarna. O wierszu Toast Jana Lechonia, [w:] Liryka polska XX wieku. Analizy i interpretacje. Seria druga, Katowice 2000.

Kisielowa J., Retoryka i melancholia. O poezji Jana Lechonia, Katowice 2001.

Kutereba K., Muzyczność w poezji dwudziestolecia międzywojennego, [w:] Cóż wiesz o pięknem? Szkice o literaturze, języku, muzyce i filmie, red. T. Mizerkiewicz, W. Ratajczak, Poznań 2007.

Lechoń J., Adam Mickiewicz, [w:] idem, O literaturze polskiej, Warszawa 1993.

Lechoń J., Dziennik, t. 1, Warszawa 1992.

Lechoń J., Poezje zebrane, oprac. R. Loth, Toruń 1995.

Lechoń J., Tradycja i nowość w literaturze polskiej, [w:] idem, O literaturze polskiej, Warszawa 1993.

Loth R., Wstęp, [w:] J. Lechoń, Poezje, oprac. R. Loth, Wrocław 1990.

Łukszo-Nowakowska W., Jan Lechoń. Zarys życia i twórczości, Warszawa 1996.

Michałowski P., „,Arka przymierza” $i$,osobna obecność”. Pamięć w poezji nowoczesnej, [w:] Poetologie pamięci, red. D. Śnieżko, Szczecin 2011.

Mickiewicz A., Wybór poezyj, t. 1, oprac. C. Zgorzelski, Wrocław 1997.

Moniuszko S., Straszny dwór. Opera w 4 aktach, oprac. J. Lefeld, Warszawa 1937.

Nawarecki A., O rzeczach, [w:] idem, Parafernalia. O rzeczach i marzeniach, Katowice 2014.

Ogiński M.K., Lesadieux à la patrie. Polonaise no. 12, wyd. Gebethner i Wolff, Warszawa 1900.

Ogiński M.K., Six polonaises du Prince Michel Ogiński. Transcrites pour le piano par Stanislas Moniuszko, Wilno 1859. 
Opacki I., Dramat narodowej wyobraźni. Wokót „Karmazynowego poematu” Jana Lechonia, [w:] idem, Król Duch, Herostrates i codzienność. Szkice, Katowice 1997.

Opacki I., Król-Duch, Herostrates i Juliusz. Trzy spotkania liryki ze Stowackim, „Pamiętnik Literacki" 1981, z. 3.

Opacki I., Lechoń i polskie mity, [w:] idem, Król Duch, Herostrates i codzienność. Szkice, Katowice 1997.

Opacki I., Wokót „Karmazynowego poematu” Jana Lechonia, „Pamiętnik Literacki” 1966, z. 4.

Opalski J., Chopin i Szymanowski w literaturze dwudziestolecia międzywojennego, Kraków 1980.

Ostasz G., W cieniu „Herostratesa”, Rzeszów 1994.

Pociej B., Bach - muzyka i wielkość, Kraków 1972, s. 18-20.

Poniatowska I., Historia muzyki polskiej, t. 5. Romantyzm, cz. 2A. Twórczość muzyczna w drugiej połowie XIX wieku, Warszawa 2010.

Przełęcki M., Metafizyczna treść muzyki, „Archiwum Historii Filozofii i Myśli Społecznej” 42, 1997.

Radion E., Audiosfera „Karmazynowego poematu” Jana Lechonia, [w:] Literatura wspótczesna w edukacji polonistycznej, t. 2. Interpretacje - wartości - konteksty, red. U. Kopeć, Rzeszów 2017.

Radion E., Percepcja wrażeń akustycznych w wierszu Mochnacki Jana Lechonia, „Acta Universitatis Lodziensis. Folia Litteraria Polonica" 2019, nr 1.

Ratajska K., Czy Lechoń w Duchu na seansie kompromitowat poezję romantyczna i mitologię narodowa?, „Acta Universitatis Lodziensis. Folia Litteraria Polonica” 2001, nr 2.

Reimann A., Muzyczny styl odbioru tekstów literackich, Poznań 2013.

Rosen Ch., The Classical Style. Haydn, Mozart, Beethoven, New York-London 1997.

Rudziński W., Moniuszko, Kraków 1972.

Sachs C., Historia instrumentów muzycznych, przeł. S. Olędzki, Kraków 1989.

Saryusz-Wolska M., Literatura i pamięć. Uwagi wstępne, [w:] Pamięć zbiorowa i kulturowa. Wspótczesna perspektywa niemiecka, red. M. Saryusz-Wolska, Kraków 2009.

Schaeffer B., Dzieje muzyki, Warszawa 1983.

Skarbowski J., Muzyczna dusza Jana Lechonia, [w:] idem, Literacki koncert polski, Rzeszów 1997.

Tatarkiewicz W., Skupienie i marzenie. Studia z zakresu estetyki, Kraków 1951.

Trybuś K., Pamięć romantyzmu. Studia nie tylko z przeszłości, Poznań 2011.

Urbanowski M., Romantyzm w literaturze dwudziestolecia międzywojennego (przechadzka historycznoliteracka), [w:] Loci (non) communes. Prace ofiarowane Profesor Marii Korytowskiej, red. O. Płaszczewska, M. Siwiec, Kraków 2017.

Urbańska M., Inspiracje Jana Lechonia, [w:] Inspiracja, red. M. Urbańska, Łódź 2019.

Wiśniewski J., Czy Maurycy Mochnacki koncertowat, grając na klawikordzie? Uwagi na marginesie wiersza Jana Lechonia, „Acta Universitatis Lodziensis. Folia Litteraria Polonica” 2001, nr 2.

Witkowski T., Konrad i erynie — Jan Lechoń, [w:] Poeci dwudziestolecia międzywojennego. Sylwetki, t. 1, red. I. Maciejewska, Warszawa 1982.

\section{Musical carriers of cultural memory in the poetry of Jan Lechon}

Summary

Jan Lechoń was a poet who actively used memory motifs in his works. These threads were very often correlated with musical and sound themes. First, this article is an attempt to show how Lechon constructed specific models of cultural memory, in which musical reminiscences played an important role. Secondly, the text shows a lot of evidence that the main method of building musical and literary 
dependencies that Lechon used was the Musicality II specified by Andrzej Hejmej, consisting in treating music as an element of a larger topic. Music in Lechon's poetry is not always treated as a value in itself. The poet often treats music, e.g. the theme of a concert or playing an instrument, as a pretext to show other content, especially those that are important to Polish cultural memory.

Keywords: Jan Lechoń, memory, music, musicality, Moniuszko, libretto, Aria with chimes 